\title{
Screening of faba bean (Vicia faba L.) accessions to acidity and aluminium stresses
}

\author{
Kiflemariam Y Belachew ${ }^{\text {Corresp., }}$ 1 , Frederick L Stoddard $^{2}$ \\ ${ }^{1}$ Department of Agricultural Sciences, Viikki Plant Science Centre, University of Helsinki, Helsinki, South Finland, Finland \\ 2 Department of Food and Environmental Sciences, Viikki Plant Science Centre, University of Helsinki, Helsinki, Finland \\ Corresponding Author: Kiflemariam Y Belachew \\ Email address: kiflemariam.belachew@helsinki.fi
}

Background. Faba bean is an important starch-based protein crop produced worldwide. Soil acidity and aluminium toxicity are major abiotic stresses affecting its production, so in regions where soil acidity is a problem, there is a gap between the potential and actual productivity of the crop. Hence, we set out to evaluate acidity and aluminium tolerance in a range of faba bean germplasm using solution culture and pot experiments.

Methods. A set of 30 accessions was collected from regions where acidity and aluminium are or are not problems. The accessions were grown in solution culture and a subset of 10 was grown first in peat and later in perlite potting media. In solution culture, morphological parameters including taproot length, root regrowth and root tolerance index were measured, and in the pot experiments the key measurements were taproot length, plant biomass, chlorophyll concentration and stomatal conductance.

Result. Responses to acidity and aluminium were apparently independent. Accessions Dosha and NC 58 were tolerant to both stress. Kassa and GLA 1103 were tolerant to acidity showing less than 3\% reduction in taproot length. Aurora and Messay were tolerant to aluminium. Babylon was sensitive to both, with up to $40 \%$ reduction in taproot length from acidity and no detectable recovery from $\mathrm{Al}^{3+}$ challenge.

Discussion. The apparent independence of the responses to acidity and aluminium is in agreement with the previous research findings, suggesting that crop accessions separately adapt to $\mathrm{H}^{+}$and $\mathrm{Al}^{3+}$ toxicity as a result of the difference in the nature of soil parent materials where the accession originated. Differences in rankings between experiments were minor and attributable to heterogeneity of seed materials and the specific responses of accessions to the rooting media. Use of perlite as a potting medium offers an ideal combination of throughput, inertness of support medium, access to leaves for detection of their stress responses, and harvest of clean roots for evaluation of their growth. Evis: 
1 Screening of faba bean (Vicia faba L.) accessions to acidity and aluminium stresses

2 Kiflemariam Y. Belachew ${ }^{1}$ and Frederick L. Stoddard ${ }^{2}$

$3{ }^{1}$ Department of Agricultural Sciences, Viikki Plant Science Centre, University of Helsinki, PO

4 Box 27 (Latokartanonkaari 5), FIN 00014, Helsinki, Finland

5 2Department of Food and Environmental Sciences, Viikki Plant Science Centre, University of

6 Helsinki, PO Box 66 (EE-building, Agnes Sjöberginkatu 2), FIN-00014, Helsinki, Finland

7 Corresponding Author: Kiflemariam Belachew

8 E-mail: kiflemariam.belachew@helsinki.fi 


\section{Abstract}

10 Background. Faba bean is an important starch-based protein crop produced worldwide. Soil acidity and aluminium toxicity are major abiotic stresses affecting its production, so in regions where soil acidity is a problem, there is a gap between the potential and actual productivity of the crop. Hence, we set out to evaluate acidity and aluminium tolerance in a range of faba bean germplasm using solution culture and pot experiments.

Methods. A set of 30 accessions was collected from regions where acidity and aluminium are or are not problems. The accessions were grown in solution culture and a subset of 10 was grown first in peat and later in perlite potting media. In solution culture, morphological parameters including taproot length, root regrowth and root tolerance index were measured, and in the pot experiments the key measurements were taproot length, plant biomass, chlorophyll concentration and stomatal conductance.

Result. Responses to acidity and aluminium were apparently independent. Accessions Dosha and NC 58 were tolerant to both stress. Kassa and GLA 1103 were tolerant to acidity showing less than 3\% reduction in taproot length. Aurora and Messay were tolerant to aluminium. Babylon was sensitive to both, with up to $40 \%$ reduction in taproot length from acidity and no detectable recovery from $\mathrm{Al}^{3+}$ challenge.

Discussion. The apparent independence of the responses to acidity and aluminium is in agreement with the previous research findings, suggesting that crop accessions separately adapt to $\mathrm{H}^{+}$and $\mathrm{Al}^{3+}$ toxicity as a result of the difference in the nature of soil parent materials where the accession originated. Differences in rankings between experiments were minor and attributable to heterogeneity of seed materials and the specific responses of accessions to the rooting media. Use of perlite as a potting medium offers an ideal combination of throughput, inertness of support medium, access to leaves for detection of their stress responses, and harvest of clean roots for evaluation of their growth. 


\section{Introduction}

Growth and yield of faba bean are determined by climatic, edaphic, and management practices that are not independent of each other and interact to affect the chemical characteristics of the soil. Soil acidity has a dramatic impact on most chemical and biological processes of a crop. Faba bean (Vicia faba L.) grows best in soils with $\mathrm{pH}$ ranging from 6.5 to 9.0 (Jensen, Peoples \& Hauggaard-Nelsen, 2010), and is considered to fare poorly at a $\mathrm{pH}$ values of 5 or less (French \& White, 2005). Nevertheless, some accessions remain productive when soil $\mathrm{pH}$ is as low as 4.5 (Singh et al., 2012), with a critical soil $\mathrm{pH}$ value of 4.0 below which assimilation of major ions decreases (Schubert, Mengel \& Schubert, 1990), and net $\mathrm{H}^{+}$release and root growth cease (Yan, Schubert \& Mengel, 1992).

Soil acidification is a worldwide problem, and sensitivity to acid soils limits the usage of faba bean in some cropping systems. Besides the simple matter of low $\mathrm{pH}$, soil acidity is associated with high availability of $\mathrm{Al}^{3+}$, which is stressful or toxic to many plants. Acid soil can be managed by the application of lime and the effect of $\mathrm{Al}^{3+}$ toxicity is ameliorated by the use of $\mathrm{P}$ containing fertilizers (Liao et al., 2006; Atemkeng et al., 2011). However, these options are not available where farmers are poor or legislation restricts fertilizer usage, they are less effective when cultivars are sensitive (Sun et al., 2008), and acidity in subsoil is harder to address than that in topsoil (Hede, Skovmand \& Lopez-Cesati, 2001; Brown et al., 2008; Zheng, 2010). Furthermore, in areas as diverse as sub-Saharan Africa and Western Australia, soil acidity has resulted in changes of cropping sequence. In Ethiopia, faba bean has been abandoned in some agricultural regions where it was previously part of the cropping system and has not been replaced by another food legume (Genanew, Argaw \& Adgo, 2012). In areas where soil acidity is severe, cereal rye cropping and livestock grazing may be the only remaining options for farmers (Genanew, Argaw \& Adgo, 2012).

Most of the studies on the inheritance of $\mathrm{Al}^{3+}$ resistance have been conducted on the major cereal crops (wheat (Triticum aestivum L. emend Thell), rice (Oryza sativa L.), and maize (Zea mays L.)) (Kochian, Pinéros \& Hoekenga, 2005), a few legumes such as soybean (Glycine max (L.) Merr.) (Liao et al., 2006), pigeon pea (Cajanus cajan L.) (Choudhary, Singh \& Kumar, 2011), and barrel medic (Medicago truncatula L.) (Narasimhamoorthy et al., 2007; Chandran et al., 2008). Studies on this trait in faba bean have been few in number. Nevertheless, wide diversity 
65

66

67

68

69

70

exists among faba bean landraces for agro-ecological adaptation (French \& White, 2005;

Wondafrash, 2006) and biotic and abiotic stress resistance (Stoddard et al., 2006; Shifa, Hussien \& Sakhuja, 2011; Khazaei et al., 2013). $\mathrm{Al}^{3+}$ toxicity tolerance of cv 'Herz Freya' was lower than that of barley and much lower than in yellow lupin and rye (Horst \& Göppel, 1986a; Horst \& Göppel, 1986b).

To identify sources of resistance to acidity and aluminium stresses, an efficient screening method is required. Solution culture, where seedlings are suspended with their roots in an aerated nutrient solution of known $\mathrm{Al}^{3+}$ concentration, is suitable for screening of tens or hundreds of accessions, and has proven useful in wheat (Stodart et al., 2007), pigeon pea (Choudhary, Singh \& Kumar, 2011; Choudhary \& Singh, 2011), barley (Hordeum vulgare L.) (Nawrot, Szarejko \& Maluszynski, 2001; Echart et al., 2002; Tamas et al., 2006), sorghum (Sorghum bicolor L.) (Hill, Ahlrichs \& Ejeta, 1989), and barrel medic (Narasimhamoorthy et al., 2007). Selected germplasm can then be tested in soil or potting mix, so differences in growth and yield can be determined.

Staining of root tips with hematoxylin, measurement of root regrowth after transfer to non-stress conditions, and relative root growth as a measure of root tolerance index after exposing plant roots to toxic levels of $\mathrm{Al}^{3+}$ are some of the techniques that are employed (Hede, Skovmand \& Lopez-Cesati, 2001) and allow simple ranking of tolerance and sensitivity (Choudhary \& Singh, 2011). Reliable results are, however, most likely to be obtained by the application of multiple procedures (Narasimhamoorthy et al., 2007).

Other morpho-physiological measures may also be informative about aluminium and acidity responses in faba bean. Leaf gas exchange was reduced by 2-3 fold in tomato cultivars as aluminium concentration increased to $50 \mu \mathrm{mol} / 1$ (Simon et al., 1994). Similarly, $0.1 \mathrm{mM}$ aluminium reduced root weight in winter wheat (Szabó-Nagy, 2015) and at pH 4, aluminium concentration of $0.13-0.15 \mathrm{mmol} / \mathrm{kg}$ significantly reduced photosynthesis, chlorophyll concentration and transpiration in wheat (Ohki, 1986). Other ionic stresses such as salinity increased chlorophyll a fluorescence level in both mung bean and Brassica seedlings (Misra, Srivastava \& Strasser, 2001).

For these reasons, we set out to evaluate acidity and aluminium tolerance in a range of faba bean germplasm. Solution culture of seedlings and pot experiments on pre-reproductive plants were 
94 both used in order to develop a reliable technique for discriminating sensitive and tolerant 95 germplasm.

96

97

98 99

100

101

102

103

104

105

106

107

108

109

110

111

112

113

114

115

116

117

118

119

120

121

122

\section{Materials and methods}

\section{Plant materials}

Thirty faba bean accessions were chosen for this study on the basis of their expected exposure to acidity or aluminium stress in their regions of provenance (Table 1). One accession had to be dropped due to inconsistent germination during the experiment. Twenty Ethiopian accessions were provided from the germplasm collection of the Ethiopian Institute of Agricultural Research, Holeta Agricultural Research Center (HARC) and the remainder were chosen from European and Canadian germplasm used in previous experiments. Acid soils are found in the wet highlands of Ethiopia where faba bean is predominantly grown. Acid soils occupy $41 \%$ of the country (Abebe, 2007), and of this area nearly one-third has an aluminium toxicity problem (Schlede, 1989). The first solution culture experiments were conducted with seed materials as received, the first pot experiment with material that had been inbred for one generation, and the second experiment with seeds from a single third-generation inbred plant of each accession.

\section{Screening for tolerance to acidity and aluminum in solution culture}

\section{Plant growing conditions}

Seeds of uniform size were selected from each of the accessions, washed three times in tap water, disinfected with $1 \% \mathrm{NaClO}$ (sodium hypochlorite) (w/v) for $5 \mathrm{~min}$ and rinsed 3 times with running tap water. The seeds were soaked in tap water for $24 \mathrm{~h}$, transferred to three layers of moist filter paper in $14 \mathrm{~cm}$ diameter Petri dishes (14-20 seeds/dish), and incubated for $72 \mathrm{~h}$ at 22 ${ }^{\circ} \mathrm{C}$ in the dark. The seedlings were then transferred to holes in a lid suspended over a plastic tray $(78 \mathrm{~cm} \times 56 \mathrm{~cm} \times 18 \mathrm{~cm})$ containing $0.5 \mathrm{mM} \mathrm{CaSO}_{4}$ solution, and grown in the dark for another 4 days in controlled-environment growth chambers at $22 / 20^{\circ} \mathrm{C}$ day/night temperatures with $70 \%$ relative air humidity. The solution was continuously aerated with an aquarium pump. Eight seedlings of each of the 29 accessions were used in each tray. Three replicates of five treatments were prepared, and arranged in a split-plot design with replicate as the block, tray (treatment) as the main plot and accession as the subplot. The replicates were separated by 21 days in time rather than physically in space, owing to space restrictions. 
123 For the remaining 7 days of the experiment, seedlings were allowed to grow on continuously

124 aerated nutrient solution comprising $4.0 \mathrm{mM} \mathrm{CaCl}_{2}, 6.5 \mathrm{mM} \mathrm{KNO}_{3}, 2.5 \mathrm{mM} \mathrm{MgCl}, 0.1 \mathrm{mM}$

$125\left(\mathrm{NH}_{4}\right)_{2} \mathrm{SO}_{4}$, and $0.4 \mathrm{mM} \mathrm{NH}_{4} \mathrm{NO}_{3}$, with fresh nutrient solution culture provided on day 4 . The $\mathrm{pH}$

126 was corrected to 7.0 (neutral control) and 4.5 (acid and aluminium treatments) with $10.88 \mathrm{M} \mathrm{HCl}$

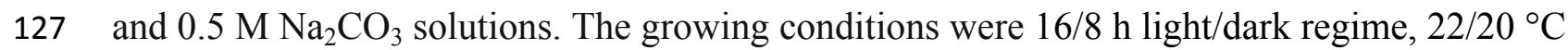

128 day/night temperatures, $70 \%$ relative air humidity and a photon flux density of $230 \mu \mathrm{mol} \mathrm{m}^{-2} \mathrm{~s}^{-1}$

129 at the plant canopy. After two days of this 7-day interval, the aluminium treatments were

130 initiated by transferring three sets of seedlings to fresh nutrient solution containing 41, 82, and

$131123 \mu \mathrm{mol} / 1$ aluminum sulfate $\left[\mathrm{Al}_{2}\left(\mathrm{SO}_{4}\right)_{3} \cdot 16 \mathrm{H}_{2} \mathrm{O}\right]$. One day later, 4 seedlings from every set of 8

132 were removed for haematoxylin staining (see below) and after a further day, the remaining

133 seedlings were transferred to aluminium-free solutions at $\mathrm{pH} 4.5$ and allowed to recover for 3

134 days, as recommended by Nava et al. (2006), bringing their total growing time to 7 days after

135 their transfer to the nutrient solution culture, the same as for those not exposed to $\mathrm{Al}^{3+}$.

136 At the end of the growth period, the length of the primary root of each seedling was measured

137 with a ruler, showing its tolerance to the stress. On the aluminium-treated seedlings, the length of

138 the primary root from the tip to the point of root thickening (callus), caused by the aluminium

139 treatment, was measured with a ruler and termed as root regrowth length. This measure

140 demonstrates the ability of the plant to recover from the stress.

141 The protocol for staining and scoring aluminium response followed Polle, Konzak \& Kittrick

142 (1978) and was based on the affinity of haematoxylin for chelated aluminium. The sets of 4

143 seedlings were transferred to distilled water with occasional shaking for $60 \mathrm{~min}$ to remove

144 aluminium from the root surface. The root tips were immersed in the hematoxylin stain $(2 \mathrm{~g} / 1$

145 hematoxylin and $0.2 \mathrm{~g} / 1$ potassium iodate $\left(\mathrm{KIO}_{3}\right)$ in distilled water) for $30 \mathrm{~min}$ and rinsed in three

146 changes of distilled water for an hour. Photographs of root tips were taken using a stereo

147 microscope fitted with an AxioCam ERc 5s imaging device and saved for later scoring of each

148 root tip.

149 Means of the 4 seedlings per replicate were used for statistical analysis.

150 Testing of acidity and aluminium response in pot experiments 
151 According to the results of solution culture, accessions representing different combination of

$152 \mathrm{Al}^{3+}$ - and acidity response (Table 2) were selected for further evaluation. The experiment was 153 conducted twice, first on peat-based medium and again on perlite.

\section{Peat growing medium}

155 The peat medium was prepared with 9 parts peat (FPM 420 F6, Kekkilä Oy, Vantaa, Finland) to 1561 part sand (v:v). The pots were 7.51 in size and were sunk into sand to prevent overheating of 157 the roots by direct sunlight. The average nutrient composition of the peat in $\mathrm{g} / \mathrm{m}^{3}$ basis included 158 nitrogen 2000, phosphorus 500, potassium 2000, and limestone (Ca and $\mathrm{Mg}$ ) 1.5. The natural $\mathrm{pH}$ 159 of the medium was 4.5 and in one-third of the pots was adjusted to $\mathrm{pH} 7.0$ by liming. Half of the

160 161 162

163

164 165

166

167

168

169

170

171

172

173

174

175

176

177

178

179 pots at $\mathrm{pH} 4.5$ were supplied with 31 of $82 \mu \mathrm{mol} / 1 \mathrm{Al}_{2}\left(\mathrm{SO}_{4}\right)_{3} \cdot 16 \mathrm{H}_{2} \mathrm{O}$ solution at sowing, and all other pots were given 31 of tap water bringing the medium to field capacity. Thus, there were three treatments, $\mathrm{pH} 7.0, \mathrm{pH} 4.5$, and $\mathrm{pH} 4.5$ with $\mathrm{Al}^{3+}$.

Plants were grown in the open air for 58 days from 28 May to 24 July 2015 at the University of Helsinki. Before sowing, seeds were inoculated with Rhizobium leguminosarum biovar. viciae (faba bean strain, Elomestari Oy, Tornio, Finland). Four seeds of each accession were sown directly in individual pots at a depth of $2 \mathrm{~cm}$ and a week after emergence they were thinned to 3 plants per pot. The experiment was terminated when plants started flowering.

\section{Perlite growing medium}

Nutrient solution culture was prepared using a complete fertilizer (Superex Peat, Kekkilä Oy, Vantaa, Finland) containing $6.8 \mathrm{mmol} / 1 \mathrm{NO}_{3}{ }^{-}, 0.9 \mathrm{mmol} / 1 \mathrm{NH}_{4}{ }^{+}, 0.29 \mathrm{mmol} / 1 \mathrm{urea}, 1.1 \mathrm{mmol} / 1$ $\mathrm{H}_{2} \mathrm{PO}_{4}^{-}, 6.7 \mathrm{mmol} / 1 \mathrm{~K}^{+}, 1 \mathrm{mmol} / 1 \mathrm{Mg}^{2+}, 27.8 \mu \mathrm{mol} / 1 \mathrm{H}_{2} \mathrm{BO}_{3}^{-}, 3.1 \mu \mathrm{mol} / 1 \mathrm{Cu}^{2+}, 48.3 \mu \mathrm{mol} / 1 \mathrm{Fe}^{2+}$, $18.2 \mu \mathrm{mol} / 1 \mathrm{Mn}^{2+}, 0.52 \mu \mathrm{mol} / 1 \mathrm{MoO}_{4}^{-2}, 4.6 \mu \mathrm{mole} / 1 \mathrm{Zn}^{2+}$, and $1 \mathrm{mmol} / 1 \mathrm{SO}_{4}{ }^{-2}$. To provide calcium, $2 \mathrm{mmol} / 1 \mathrm{CaCl}_{2}$ was added. According to the $\mathrm{pH}$ requirement of the nutrient solutions for each treatment, the $\mathrm{pH}$ of the solution was adjusted using $\mathrm{HCl}$ and $\mathrm{Na}_{2} \mathrm{CO}_{3}$.

Plants were grown in an open-sided greenhouse cage for 42 days from 18 May to 30 June 2016 at the University of Helsinki. For each plant, two 3-1 pots were stacked on top of each other in order to provide depth for rooting. Each pot was $20 \mathrm{~cm}$ deep and $15 \mathrm{~cm}$ in diameter, with 4 drainage holes that were $2 \mathrm{~cm}$ in diameter in the bottom pots and $3 \mathrm{~cm}$ in the top pots, so the impairment of root growth was minimal. The bottom pots were filled with 21 of perlite and 11 of 
180 fine sand on top of the perlite to hold the top pot firmly, and the top pots were filled with 31 of 181 perlite. Two seeds per top pot were planted and each pot was irrigated with tap water to field

182

183

184

185

186

187

188

189

190

191

192

193

194

195

196

197

198

199

200

201

202

203

204

205

206

207

208 capacity. Plants were thinned to one per top pot after five days. For 10 days after sowing, pots were watered with $200 \mathrm{ml}$ of tap water every other day. Thereafter, each pot received $200 \mathrm{ml}$ of nutrient solution of the corresponding treatment every other day for 32 days. Treatments were implemented by fertigation with neutral $\mathrm{pH}$ (7.0) nutrient medium, acid medium at $\mathrm{pH} 4.5$, and $\mathrm{pH} 4.5+82 \mu \mathrm{mol} / 1 \mathrm{Al}_{2}\left(\mathrm{SO}_{4}\right)_{3} \cdot 16 \mathrm{H}_{2} \mathrm{O}$. The experiment was terminated when plants started flowering, even though this was fewer days than in the peat experiment.

\section{Experimental design}

The peat and perlite experiments were a split-plot design, with 4 replicate blocks, 3 treatments (neutral, acid and aluminium) as the main plots and accessions as subplot.

\section{Data collected}

\section{Peat experiment}

The rate of leaf photosynthesis and stomatal conductance were measured using a LI-6400 Portable Photosynthesis System (LI-COR, Lincoln, Nebraska, USA) at $1400 \mu \mathrm{mole} / \mathrm{m}^{2} / \mathrm{s}$ radiation level and adjusted cooling temperature of $25^{\circ} \mathrm{C}$, on $6 \mathrm{~cm}^{2}$ leaf area in bright sunlight from 11:00 a.m. to 2:00 p.m. One leaf per pot was used, chosen from the middle of the shoot having been fully exposed to direct sunlight at 25, 35, and 45 days after sowing. Leaf chlorophyll concentration was measured using an optical chlorophyll meter, SPAD-502 (Minolta Camera Co, Ltd, Japan), on the same days. Two leaves per plant were measured and the average of the two was recorded. Data from 35 days after sowing are presented here.

At the end of the experimental period, 52 days after sowing, the leaves of each plant in the pot (3 plants per replication) were severed from the stem and the total leaf area was measured using a LI-COR Model LI-3000A Portable Area Meter (LI-COR, U.S.A.) and the average values were calculated for each replicate. Plant roots were carefully removed from both the pot and the peat and scored for nodule quantity and quality. Nodule quantity was measured by two people scoring, zero for absent, 1 for a few nodules, 2 moderate quantity, and 3 for prolific nodule production. Similarly, nodule quality was also scored by two people as follows. " 0 " was given 
209 for absent, " 1 " was given when $>50 \%$ of the nodules were white in color, "3" was given when

$210>50 \%$ of the nodules were pink in color, "2" was given when each white and pink nodules were

211 nearly equal by numerous. In both cases, the average of the two scores were taken as a value of

212 each unit of plant per replication. Finally, the root and shoot dry weight were taken after drying

213 the biomass in oven at $76{ }^{\circ} \mathrm{C}$ for 48 hours. Samples of shoot and potting medium were taken for 214 aluminium analysis.

\section{Perlite experiment}

216 On day 41, stomatal conductance was measured using a Leaf Porometer (Decagon Devices, Inc,

217 Pullman WA, U.S.A.) once per plant. On day 42, canopy temperature was measured using a

218 FLUKE Model 574 Precision Infrared Thermometer (Fluke Corporation, Everett, WA, U.S.A.)

219 and leaf chlorophyll concentration was measured using the SPAD-502 as described above. Roots

220 were carefully removed from the perlite and taproot length was measured with a ruler. The root

221 and shoot dry weight were determined as described above. Root to shoot dry weight ratio was

222 calculated by dividing the root weight by the corresponding shoot weight.

\section{Aluminium concentration analysis}

225

226

227

228

229

230

231

232

233

234

235

236

Samples of shoot and growing media were milled and representative $250 \mathrm{mg}$ sub-samples were digested with acid in a microwave oven (Mars Express, CEM, USA) conforming to EPA 3052 (9 $\mathrm{ml} 70 \% \mathrm{HNO}_{3}$ and $1 \mathrm{ml} 30 \% \mathrm{H}_{2} \mathrm{O}_{2}$ at $1600 \mathrm{~W}$ and $175^{\circ} \mathrm{C}$; EPA, 1996). The concentration of $\mathrm{Al}$ was measured with inductively coupled plasma- optical emission spectrometry (ICP-OES), Thermo Scientific iCAP 6000 Series (Thermo Fisher Scientific, Waltham, MA USA). The limit for detection of Al by the ICP was $0.032 \mathrm{mg} / 1$.

\section{Data analysis}

Analysis of variance was conducted using SPSS version 22.0 (IBM Inc., Chicago, IL, USA) software package. Accession and culture media were treated as fixed effects and replicate as a random effect in the split-plot design. Treatment means were separated by LSD (5\%).

\section{Results}

\section{Solution culture experiment}


237 Taproot length at $\mathrm{pH} 7.0$ ranged from $18 \mathrm{~cm}$ in Gora to $27 \mathrm{~cm}$ in Obse and EK02016-1, and at $238 \mathrm{pH} 4.5$ from $14.8 \mathrm{~cm}$ in Tesfa to $22.9 \mathrm{~cm}$ in Dosha (both $\mathrm{P}<0.05$; Figure 1). Accessions Kassa, 239 NC58 and GLA1103, all showed less than 3\% reduction in root length in acid condition, whereas

2408 accessions showed significant reductions, with the greatest in Tesfa, Divine and EH06006-6

241 which showed $30-40 \%$ setback.

242 Two of the three aluminium treatments were relatively uninformative. The difference in mean 243 root lengths between the 0 and $41 \mu \mathrm{mol} / \mathrm{l}$ aluminium treatments was not statistically significant

244 (1.2 cm longer with aluminium than without). The $123 \mu \mathrm{mol} / 1$ treatment did not result in a 245 significant difference in root length from the $82 \mu \mathrm{mol} / 1$ treatment, and very few of the roots 246 regrew, so it appeared to be too strong a dose. Hence, only the $82 \mu \mathrm{mol} / 1$ treatment provided 247 informative results and we present only those here.

248 Roots grown in aluminium-free solutions did not stain with haematoxylin (Figure 2A). The 249 minimum haematoxylin stain score in the $82 \mu \mathrm{mol} / 1$ treatment was found in Dosha, followed by 250 Gebelcho, while the maximum was in Babylon, followed by Degaga $(\mathrm{P}<0.05$; Table 1$)$.

251 Babylon showed no apparent root regrowth following transfer to aluminium-free solution, 252 whereas Hachalu showed the most vigorous regrowth $(\mathrm{P}<0.05)$. Accessions EH06006-1, 253 followed by Kontu, Messay, and Aurora, all produced longer roots in the $82 \mu \mathrm{mol} / \mathrm{l}$ aluminium 254 treatment than in the acid treatments (Figure 1), although these differences were not significant. 255 Aluminium treatment caused significant reductions in root growth in Gora and Walki.

256 Summing the ranks of hematoxylin staining, root regrowth, and root length setback by 257 aluminium (Table 1) indicated that Gebelcho, Aurora and Messay were the three most tolerant 258 accessions, whereas Kassa, Babylon and Divine were the most susceptible.

259 Comparison of these results showed that acidity response and aluminium responses have some 260 independence. On this basis, 10 accessions were chosen for further experiments (Table 2).

\section{Experiments in peat and perlite potting media}

262 In the peat experiment, leaf area was significantly different in all 3 treatments, neutral $>$ 263 aluminium $>$ acid, but leaf temperature did not show significant effects of treatment. Rate of 264 photosynthesis increased in the order neutral $<$ acid $<$ aluminium, and shoot dry matter was 265 greatest in the aluminium treatment. Nodule quantity, nodule quality and root dry matter were all 
266 highest in the neutral treatment with no significant difference between acid and aluminium

267 treatments (Table 3). Similarly, shoot dry weight and root to shoot dry weight ratio were highest

268 in neutral treatment. Chlorophyll concentration and stomatal conductance were significantly

269 lower in the neutral treatment than in the other two, which did not significantly differ (Table 4).

270 In the perlite experiment, many results were similar. Chlorophyll concentration was again

271 significantly lower in the neutral than in the other two treatments (Table 4). Babylon and GLA

2721103 showed high leaf chlorophyll concentration in both acid and aluminium treatments. On the

273 other hand, Kassa in the acid, and NC 58, Gebelcho and Messay in the aluminium treatment

274 showed low chlorophyll concentrations (Figure 3A). There was no significant difference in

275 stomatal conductance or leaf temperature between treatments. Differences in root and shoot dry

276 matter were also not significant. Root length, however, was significantly greater in the neutral

277 treatment than the other two. In Aurora, Babylon, EH 06006-6, Messay and Tesfa, the setback

278 due to acidity was greater than the LSD, but in the other 5 accessions the effect of acidity was

279 very small (Figure 3B). The effect of aluminium on reducing root length was significant in Kassa,

280 whereas Gebelcho, Dosha and Aurora showed slightly greater taproot length under aluminium

281 stress.

282 Chlorophyll concentration in the two pot experiments showed similar effects of accessions

283 except that Aurora was an outlier (Table 4). Without Aurora, the correlation coefficient of the

284 other 9 accessions was $0.853(\mathrm{P}<0.01)$. Stomatal conductance values in the two experiments

285 were also highly correlated, again with the exception of Aurora, and with the same r value. Root

286 and shoot dry weights, however, were not significantly correlated between the two experiments.

287 Aurora produced the largest shoot and second largest roots in peat, whereas EH 06006-6 did so

288 in perlite.

\section{Shoot and growing medium Al concentration}

290 There was no significant difference between treatment means in shoot aluminium accumulation

291 (Table 3). However, there was a highly significant difference among accessions, with Babylon

292 followed by Aurora showing low shoot Al concentration. Aluminium concentration in peat

293 growing medium was far higher in aluminium-treated medium at $1107 \mathrm{mg} / \mathrm{kg}$ than the other two

294 (150 mg/kg neutral, $124 \mathrm{mg} / \mathrm{kg}$ acid). 


\section{Discussion}

296 Great variation among accessions was observed in acidity tolerance ranging from below 3\% to

$29740 \%$ setback in taproot growth. Similarly, accessions showed variable responses to aluminium

298 treatments ranging from no apparent taproot regrowth to prolific root elongation during recovery

299 after being exposed to aluminium treatment. Generally, accessions showed independent tolerance

300 to acidity and aluminium treatments (Table 2). Accessions tending to tolerate both acidity and

301 aluminium were found to be moderately tolerant. The independence of these responses to acidity

302 and aluminium is in agreement with Kidd \& Proctor (2001), who showed that crop accessions

303 separately adapt to $\mathrm{H}^{+}$and $\mathrm{Al}^{3+}$ toxicity as a result of the difference in the nature of soil parent

304 materials (organic vs mineral) where the accession originated.

305 In general, the results obtained in solution culture experiment were confirmed in the two pot

306 experiments. Babylon, however, performed unexpectedly well in the peat experiment in

307 comparison with the other experiments, and results of leaf traits of Aurora were outliers in the

308 regression of the peat and perlite experiments. Part of this difference may be attributed to

309 heterogeneity of the samples, as the experiments were started with material as received, and part

310 to specific responses of accessions to the rooting media. The heterogeneity was also shown in the

311 highly variable responses to hematoxylin staining within some accessions. Nevertheless, results

312 of the perlite experiment, conducted using third-generation inbred seed materials, showed great

313 similarity with those of the solution culture experiment (compare Figures 1 and 3B). Inbreeding

314 of accessions to produce lines that are as homozygous as possible is well known to be necessary

315 in cross-pollinated crops like faba bean.

316 The combination of reduced leaf size and increased chlorophyll concentration was indicative of

317 stress due to either acidity or aluminium. Multiplying these two values together (e.g., from the

318 treatment means in Tables 3 and 4) showed that even though the chlorophyll concentration was

319 higher in the stress treatments, chlorophyll content per plant was lower. By these measures,

320 certain accessions showed little stress from one or the other treatment, particularly in the perlite

321 experiment, as confirmed by their root lengths and stomatal conductance values. Those

322 accessions reported in solution culture experiment as tolerant in either of the stresses, such as

323 Kassa in the acid treatment, showed lower chlorophyll concentrations in the tolerated stress

324 treatment, whereas those accessions reported as sensitive to acid and/or aluminum stress, such as 
325 Babylon, showed higher concentrations (Figure 3A). Similarly, GLA 1103 (aluminium sensitive)

326 and NC 58 and Messay (aluminium tolerant) showed the highest and the lowest photosynthesis

327 rates in aluminium treatment (Table 3), respectively. In certain accessions of wheat, a relatively

328 low concentration $(16 \mu \mathrm{mol} / \mathrm{l})$ of $\mathrm{Al}$ increased chlorophyll a and b concentrations (Alamgir \&

329 Akhter, 2010), but $130 \mu \mathrm{mol} / 1$ decreased leaf chlorophyll concentration (Ohki, 1986).

330 Shoot Al concentration analysis indicated conflicting results among Al-tolerant accessions. The

331 shoot Al concentrations of Aurora, Gebelcho and Dosha was low, whereas those of NC 58 and

332 Messay were relatively high (Table 3), and the accession by treatment interaction was not

333 statistically significant. Faba bean can exclude aluminium by chelation with exuded citrate (Chen

334 et al., 2012), and this would be seen as stronger hematoxylin in susceptible accessions, as shown

335 for wheat (Polle, Konzak \& Kittrick 1978). Its mechanism of Al tolerance may also include

336 sequestration, as found in other species (Osaki, Watanabe \& Tadano, 1997).

337 In terms of taproot growth along with root and shoot dry weights, accessions responded in 338 several ways to the acidity and aluminum treatments. There was significant variation among 339 treatments in taproot length (neutral > acid >aluminium) but not in root dry weight, showing that 340 roots were shorter and thicker in stressed conditions that otherwise. Taproot length of tolerant 341 accessions including GLA 1103, NC 58 and Kassa was not affected by acidity, whereas that of

342 Aurora, Tesfa and Babylon was severely affected. Similarly, Kassa, Babylon, Tesfa and EH

343 06006-6 were greatly affected by the chosen concentration of aluminium, but the root lengths of

344 Gebelcho, Dosha and Aurora were slightly longer under this stress (Figure 3B). While this

345 increase was not statistically significant, it was consistent with proposed root growth

346 enhancement properties of aluminium under acidic conditions (Kinraide, 1993; Osaki, Watanabe

$347 \&$ Tadano, 1997). In Al-stimulated plants, such as, Acacia mangium Willd. and some lines of

348 Oryza sativa L. (Osaki, Watanabe \& Tadano, 1997), available $\mathrm{Al}^{3+}$ at $44 \mu \mathrm{mol} / 1$ concentration

349 applied as $\mathrm{Al}_{2}\left(\mathrm{SO}_{4}\right)_{3}$ was reported to increase the activity of roots for $\mathrm{P}$ uptake and initiation of 350 many laterals.

351 The rhizotoxicities of $\mathrm{Al}^{3+}$ and $\mathrm{H}^{+}$, may partially alleviate each other, due to the competition of 352 the positively charged cations for binding sites of the negatively charged epidermal layers of the 353 roots (Kinraide \& Parker 1987; Kinraide et al. 1992). At low soil pH, $\mathrm{Al}^{3+}$ has a stronger effect 354 in amelioration of toxicity that is caused by cations such as $\mathrm{H}^{+}, \mathrm{Na}^{+}, \mathrm{K}^{+}, \mathrm{Ca}^{2+}$, and $\mathrm{Mg}^{2+}($ Fawzy, 
355 Overstreet \& Jacobson, 1954; Kinraide \& Parker, 1987; Kinraide, Ryan \& Kochian, 1992; Yan,

356 Schubert \& Mengel, 1992; Kinraide, 1993; Kinraide, 2003). This reciprocal alleviation is

357 probably the reason for the observed slight increase in taproot length and the development of

358 smooth root surface (without callus marking) in some accessions treated with $41 \mu \mathrm{mol} / 1 \mathrm{Al}^{3+}$ in

359 the first experiment.

360 There was an important effect of $\mathrm{pH}$ but not of aluminium on nodule quantity and quality. Low

$361 \mathrm{pH}$ reduced nodule mass by $48 \%$ and nodule quality by $29 \%$. Similarly, acidity significantly

362 decreased nodule numbers (as much as 20-33\%) and activity in red clover inoculated by two

363 different bacterial strains (Shirokikh, Shirokikh \& Ustyuzhanin, 2005). Decreased plant

364 dependence on fixed nitrogen was reported in subterranean clover (Trifolium subterraneum L.)

365 growing in low soil pH and high soil aluminium (Unkovich, Sanford \& Pate, 1996). Correa,

366 Aranda \& Barneix (2001) reported that alfalfa (Medicago sativa L.) and Lotus glaber Mill.

367 varied in their nodulation and nitrogen fixation ability at $\mathrm{pH} 4.0$ due to variation in host and/or

368 strain tolerance to low $\mathrm{pH}$. In this study, only one inoculum was used, so we were unable to test

369 the effect of its genotype, but it is known that rhizobium symbionts of faba bean differ in their

370 sensitivity to low $\mathrm{pH}$, and their sensitivity to $\mathrm{Al}$ concentration depends on the other ions in the

371 solution (Kinraide \& Sweeney, 2003; Bayoumi Hamuda et al., 2009).

\section{Conclusion}

373 Responses to acidity and aluminium toxicity were independent. A concentration of $82 \mu \mathrm{mol} / 1$

374 aluminum sulfate $\left[\mathrm{Al}_{2}\left(\mathrm{SO}_{4}\right)_{3} \cdot 16 \mathrm{H}_{2} \mathrm{O}\right]$ was suitable for discriminating the sensitivity of faba bean

375 accessions, whereas $41 \mu \mathrm{mol} / 1$ had too little effect on root growth and $123 \mu \mathrm{mol} / 1$ was too much.

376 Taproot length, root length setback by treatment and root regrowth procedures were found to be

377 sound methods for preliminary screening of accessions for acidity and aluminium tolerance. At a

378 later stage, taproot length, root and shoot biomass coupled with chlorophyll concentration and

379 stomatal conductance provided reliable discrimination between accessions. Results, generally

380 agreed between experiments, with some differences attributable to uniformity of seed and to

381 specific responses of rooting medium.

382 High throughput screening for acidity and Al tolerance at an early stage of seedling growth was 383 possible in the solution culture growth medium. Nevertheless, for further screening of faba bean 384 accessions for an extended growth period, perlite was found to be an appropriate medium owing 
385 386

387

388

389

390

391

392

393

394

395

396

397

398

399

400

401

402

403

404

405

406

407

408

409

410

411

412

413

414

415

to its inert nature, free drainage allowing changes of treatment medium, provision of support for plants allowing monitoring of leaf and shoot responses to the acidity and aluminium stresses, and easy extraction of entire root systems for evaluation without encumbering medium.

Kassa, GLA 1103, Aurora, Messay, NC 58 and Babylon were selected for future breeding, genetics and physiological studies on Al tolerance in faba bean.

\section{Acknowledgement}

We acknowledge Gemechu Keneni for his help during seed collection in Ethiopia and Marjo Kilpinen, Markku Tykkyläinen, Jouko Närhi and Sanna Peltola for their support in the laboratory and greenhouse activities during the conduct of the research, and Mikko Lehtonen for his assistance with microscope imaging at the University of Helsinki, Finland. Finally, we also thank Pertti Pärssinen for his valuable comments and remarks during the development of the manuscript. We extend our thanks to the Holeta Agricultural Research Centre for providing us 20 Ethiopian faba bean accessions and the Ethiopian Biodiversity Institute for its support to export the samples from Ethiopia to Finland.

\section{References}

Abebe M. 2007. Nature and management of acid soils in Ethiopia. Ethiopian Institute of Agricultural Research, Addis Ababa, Ethiopia, 1-99.

Alamgir ANM, Akhter S. 2010. Effects of aluminium on some biochemical characteristics of wheat (Triticum aestivum L.). Bangladesh Journal of Botany 39:9-14.

Atemkeng M F, Muki T J, Park J, Jifon J. 2011. Integrating molecular tools with conventional breeding strategies for improving phosphorus acquisition by legume crops in acid soils of subSaharan Africa. Biotechnology and Molecular Biology Reviews 6:142-154.

Bayoumi Hamouda HEAF, Orosz E, Hamuda Y, Tóth N, Kecskès M. 2009. Vicia fabaRhizobium leguminosarum system symbiotic relationship under stress of soil $\mathrm{pH}$ and aluminium. Tájökológiai Lapok 7:301-318.

Brown TT, Koenig RT, Huggins DR, Harsh JB, Rossi RE. 2008. Lime effects on soil acidity, crop yield, and aluminum chemistry in direct-seeded cropping systems. Soil Science Society of America Journal 72:634-40.

Chandran D, Sharopova N, VandenBosch KA, Garvin DF, Samac DA. 2008. Physiological and molecular characterization of aluminum resistance in Medicago truncatula. BMC Plant Biology $8: 89$. 
416 Chen Q, Wu K-H, Zhang Y-N, Phan X-H, Li K-Z, Yu Y-X, Chen L-M. 2012. Physiological and 417 molecular responses of broad bean (Vicia faba L.) to aluminum stress. Acta Physiologiae 418 Plantarum 34:2251-2263.

419 Choudhary AK, Singh D. 2011. Screening of pigeonpea genotypes for nutrient uptake efficiency 420 under aluminum toxicity. Physiology and Molecular Biology of Plants 17:145-152.

421 Choudhary AK, Singh D, Kumar J. 2011. A comparative study of screening methods for 422 tolerance to aluminum toxicity in pigeon pea [Cajanus cajan (L.) Millspaugh]. Australian 423 Journal of Crop Science 5:1419-1426.

424 Correa OS, Aranda A, Barneix AJ. 2001. Effect of $\mathrm{pH}$ on growth and nodulation of two forage 425 legumes. Journal of Plant Nutrition 24:1367-1375.

426 Echart CL, Barbosa-Neto, J'F, Garvin DF, Cavalli-Molina S. 2002. Aluminum tolerance in 427 barley: Methods for screening and genetic analysis. Euphytica 126:309-313.

428 EPA (US Environmental Protection Agency). 1996. SW-846 Test method 3052: Microwave assisted acid digestion of siliceous and organically based matrices. Available at https://www.epa.gov/hw-sw846/sw-846-test-method-3052-microwave-assisted-acid-digestionsiliceous-and-organically-based (accessed 24 October 2016).

432 Fawzy H, Overstreet R, Jacobson L. 1954. The Influence of Hydrogen Ion Concentration on 433 Cation Absorption by Barley Roots. Plant physiology 29:234-237.

434 French B, White P. 2005. Soil and environmental factors affecting pulse adaptation in Western 435 Australia. Australia Journal of Agricultural Research 50:375-387.

436 Genanew T, Argaw M, Adgo E. 2012. Farmers soil management practices and their perceptions 437 to soil acidity, at Ankesha District of Awi Zone, Northwestern Ethiopia. Libyan Agriculture

438 Research Center Journal International 3: 64-72.

439 Hede AR, Skovmand B, Lopez-Cesati J. 2001. Acid soils and aluminum toxicity. In: Reynolds 440 MP, Ortiz-Monasterio JI, McNab A. eds. Application of physiology in wheat breeding. Mexico, 441 D.F.: CIMMYT, Chapter 15, 172-182.

442 Hill PR, Ahlrichs JL, Ejeta G. 1989. Rapid evaluation of sorghum for aluminum tolerance. Plant 443 and Soil 114:85-90.

444 Horst W, Göppel H. 1986a. Al tolerance of horse bean, yellow lupin, barley and rye. I. Shoot and 445 root-growth as affected by al supply. Zeitschrift fur Pflanzenernahrung und Bodenkunde 149:8344693.

447 Horst W, Göppel H. 1986b. Aluminium-Toleranz von Ackerbohne (Vicia faba), Lupine (Lupinus 448 luteus), Gerste (Hordeum vulgare) und Roggen (Secale cereale). II. Mineralstoffgehalte in Sproß 449 und Wurzeln in Abhängigkeit vom Aluminium-Angebot. Zeitschrift für Pflanzenernährung und 450 Bodenkunde 149:94-109.

451 Jensen ES, Peoples MB, Hauggaard-Nielsen H. 2010. Faba bean in cropping systems. Field 452 Crops Research 115: 203-216. 
453 Khazaei H, Street K, Bari A, Mackay M, Stoddard FL. 2013. The FIGS (Focused Identification 454 of Germplasm Strategy) approach identifies traits related to drought adaptation in Vicia 455 faba genetic resources. PLOS ONE 8: e63107.

456 Kidd PS, Proctor J. 2001. Why plants grow poorly on very acid soils: are ecologists missing the 457 obvious? Journal of Experimental Botany 52:791-799.

458 Kinraide TB. 1993. Aluminum enhancement of plant growth in acid rooting media. A case of 459 reciprocal alleviation of toxicity by two toxic cations. Physiologia Plantarum 88:619-625.

460 Kinraide TB. 2003. Toxicity factors in acidic forest soils: attempts to evaluate separately the 461 toxic effects of excessive $\mathrm{Al}^{3+}$ and $\mathrm{H}^{+}$and insufficient $\mathrm{Ca}^{2+}$ and $\mathrm{Mg}^{2+}$ upon root elongation. 462 European Journal of Soil Science 54:323-33.

463 Kinraide TB, Parker DR. 1987. Cation amelioration of aluminum toxicity in wheat. Plant 464 Physiology 83:546-551.

465 Kinraide TB, Ryan PR, Kochian LV. 1992. Interactive effects of $\mathrm{Al}^{3+}, \mathrm{H}^{+}$, and other cations on 466 root elongation considered in terms of cell-surface electrical potential. Plant Physiology 467 99:1461-1468.

468 Kinraide TB, Sweeney BK. 2003. Proton alleviation of growth inhibition by toxic metals (A1, La, $469 \mathrm{Cu}$ ) in rhizobia. Soil Biology and Biochemistry 35:199-205.

470 Kochian, LV, Piñeros MA, Hoekenga WA. 2005. The physiology, genetics and molecular 471 biology of plant aluminum resistance and toxicity. Plant and Soil 274:175-195.

472 Liao H, Wan H, Shaff J, Wang X, Yan X, Kochian LV. 2006. Phosphorus and aluminum 473 interactions in soybean in relation to aluminum tolerance: Exudation of specific organic acids 474 from different regions of the intact root system. Plant Physiology 141:674-684.

475 Llugany M, Poschenrieder C, Barceló J. 1995. Monitoring of aluminium-induced inhibition of 476 root elongation in four maize cultivars differing in tolerance to aluminium and proton toxicity.

477 Physiologia Plantarum 93:265-271.

478 Misra AN, Srivastava A, Strasser RJ. 2001. Utilization of fast chlorophyll a fluorescence 479 technique in assessing the salt/ion sensitivity of mung bean and Brassica seedlings. Journal of 480 Plant Physiology 158:1173-1181.

481 Narasimhamoorthy B, Blancaflor EB, Bouton JH, Payton ME, Sledge MK. 2007. A comparison 482 of hydroponics, soil, and root staining methods for evaluation of aluminum tolerance in 483 Medicago truncatula (Barrel Medic) germplasm. Crop Science 47:321-328.

484 Nava IC, Delatorre CA, de Lima Duratie IT, Pacheco MT, Federizzi LC. 2006. Inheritance of 485 aluminum tolerance and its effects on grain yield and grain quality in oats (Avena sativa L.). 486 Euphytica 148:353-358

487 Nawrot M, Szarejko I, Maluszynski M. 2001. Barley mutants with increased tolerance to 488 aluminium toxicity. Euphytica 120: 345-356. 
489

490

491

492

493

494

495

496

497

498

499

500

501

502

503

504

505

506

507

508

509

510

511

512

513

514

515

516

517

518

519

520

521

522

523

Ohki K. 1986. Photosynthesis, chlorophyll, and transpiration responses in aluminium stressed wheat (Triticum aestivum L.) and sorghum (Sorghum bicolor). Crop Science 26:572-575.

Osaki M, Watanabe T, Tadano T. 1997. Beneficial effect of aluminium on growth of plants adapted to low pH soils. Soil Science and Plant Nutrition 43:551-563.

Polle E, Konzak CF, Kittrick JA. 1978. Visual detection of aluminum tolerance levels in wheat by hematoxylin staining of seedlings roots. Crop Science 18:823-827

Schlede H. 1989. Distribution of acid soils and liming materials in Ethiopia. Ethiopian Institute of Geological Survey, Ministry of Mines and Energy, Addis Ababa, Ethiopia.

Schubert E, Mengel K, Schubert S. 1990. Soil pH and calcium effect on nitrogen fixation and growth of broad bean. Agronomy Journal 92:967-969.

Shifa H, Hussien T, Sakhuja PK. 2011. Association of faba bean rust (Uromyces viciae-fabae) with environmental factors and cultural practices in the Hararghe highlands, Eastern Ethiopia. East African Journal of Sciences 5:58-65.

Shirokikh AA, Shirokikh IG, Ustyuzhanin IA. 2005. Reaction of legume-rhizobial symbiotic systems to stress caused by acidity and aluminium toxicity [abstract no. 20053142158]. Russian Agricultural Sciences 8:9-12.

Simon L, Kieger K, Sung SS, Smalley TT. 1994. Aluminium toxicity in tomato. Part 2. Leaf gas exchange, chlorophyll content, and invertase activity. Journal of Plant Nutrition 17:307-317.

Singh AK, Bhatt BP, Upadhyaya A, Kumar S, Sundaram PK, Singh BK, Chandra N, Bharati RC. 2012. Improvement of faba bean (Vicia faba L.) yield and quality through biotechnological approach: a review. African Journal of Biotechnology 11:15264-15271.

Stodart BJ, Raman EH, Coombes EN, Mackay EM. 2007. Evaluating landraces of bread wheat (Triticum aestivum L.) for tolerance to aluminum under low $\mathrm{pH}$ conditions. Genetic Resources and Crop Evolution 54:759-766.

Stoddard FL, Balko C, Erskine W, Khan HR, Link W, Sarker A. 2006. Screening techniques and sources of resistance to abiotic stresses in cool-season food legumes. Euphytica 147:167-186. DOI: $10.1007 / \mathrm{s} 10681-006-4723-8$.

Sun QB, Shen RF, Zhao XQ, Chen RF, Dong XY. 2008. Phosphorus enhances Al resistance in Al-resistant Lespedeza bicolor but not in Al-sensitive L. cuneata under relatively high Al stress. Annals of Botany 102:795-804.

Szabó-Nagy A. 2015. Aluminium toxicity in winter wheat. ACTA University Sapientiae, Alimentaria, 8:95-405.

Tamas L, Budikova S, Simonovicova M, Huttova J, Siroka B, Mistrik I. 2006. Rapid and simple method for Al-toxicity analysis in emerging barley roots during germination. Biologia Plantarum 50:87-93. 
524 Unkovich MJ, Sanford P, Pate JS. 1996. Nodulation and nitrogen fixation by subterranean clover 525 in acid soils as influenced by lime application, toxic aluminium, soil mineral N, and competition 526 from annual ryegrass. Soil Biology and Biochemistry 28:639-648.

527 Wondafrash M. 2006. Faba bean variety development for high altitude and vertisol areas of 528 North Shewa. Amhara Regional Agricultural Research Institute, Proc. of the $1^{\text {st }}$ Annual Regional 529 Conference on Completed Crop Research (pp. 159-164), Bahir Dar, Ethiopia.

530 Yan F, Schubert S, Mengel K. 1992. Effect of low root medium pH on net proton release, root 531 respiration, and root growth of corn (Zea mays L.) and broad bean (Vicia faba L.). Plant 532 Physiology 99:415-421.

533 Zheng SJ. 2010. Crop production on acid soils: overcoming aluminum toxicity and phosphorus 534 deficiency. Annals of Botany 106:183-184. 
535 Table 1. The 29 accessions of faba bean, their country of origin and source, and their response to $53682 \mu \mathrm{mol} / 1 \mathrm{Al}^{3+}$ in solution culture, $\mathrm{n}=3$.

\begin{tabular}{|c|c|c|c|c|c|c|c|c|c|}
\hline \multirow[b]{3}{*}{ Accession } & \multirow[b]{3}{*}{ Country } & \multirow{3}{*}{ Origin } & \multicolumn{7}{|c|}{ Aluminium responses } \\
\hline & & & \multicolumn{2}{|c|}{ Haematoxylin stain } & \multicolumn{2}{|c|}{ Root regrowth } & \multicolumn{2}{|c|}{$\begin{array}{c}\text { Al root } \\
\text { tolerance } \\
\text { index }(82 \\
\mu \mathrm{mol} / 1 \mathrm{Al}^{3+} / \\
\left.0 \mu \mathrm{mol} / 1 \mathrm{Al}^{3+}\right)\end{array}$} & \multirow[b]{2}{*}{$\begin{array}{c}\text { Rank } \\
\text { sum }\end{array}$} \\
\hline & & & Score & Rank & $\begin{array}{l}\text { Length } \\
(\mathrm{cm})\end{array}$ & Rank & Value & Rank & \\
\hline Alexia & Austria & Gleisdorf & 1.5 & 14 & 0.2 & 2 & 1.04 & 21 & 37 \\
\hline Aurora & Sweden & Svalöf Weibull & 1.3 & 20 & 0.8 & 20 & 1.14 & 25 & 65 \\
\hline Babylon & Netherlands & Nickerson Limagrain & 2.8 & 1 & 0.0 & 1 & 0.98 & 15 & 17 \\
\hline Bulga 70 & Ethiopia & HARC & 1.8 & 9 & 0.3 & 5 & 0.97 & 13 & 27 \\
\hline CS 20 DK & Ethiopia & HARC & 1.9 & 7 & 0.2 & 4 & 1.03 & 19 & 30 \\
\hline Degaga & Ethiopia & HARC & 2.4 & 2 & 0.4 & 8 & 1.14 & 26 & 36 \\
\hline Divine & France & INRA & 1.7 & 12 & 0.4 & 9 & 0.82 & 4 & 25 \\
\hline Dosha & Ethiopia & HARC & 0.8 & 24 & 1.3 & 26 & 0.95 & 12 & 62 \\
\hline ЕH 06006-6 & Ethiopia & HARC & 1.7 & 10 & 0.3 & 6 & 1.47 & 29 & 45 \\
\hline EK 02016-1 & Ethiopia & HARC & 1.6 & 13 & 0.8 & 18 & 1.04 & 20 & 51 \\
\hline Fatima & Canada & Univ. Saskatchewan & 2.1 & 4 & 1.3 & 25 & 0.89 & 9 & 38 \\
\hline Gebelcho & Ethiopia & HARC & 1.0 & 23 & 0.9 & 21 & 1.07 & 22 & 66 \\
\hline GLA 1103 & Austria & Gleisdorf & 1.8 & 8 & 0.5 & 11 & 0.99 & 16 & 35 \\
\hline Gora & Ethiopia & HARC & 1.3 & 19 & 0.4 & 10 & 0.59 & 1 & 30 \\
\hline Hachalu & Ethiopia & HARC & 1.4 & 17 & 1.5 & 28 & 1.03 & 18 & 63 \\
\hline Holetta-2 & Ethiopia & HARC & 1.3 & 21 & 0.6 & 13 & 0.93 & 10 & 44 \\
\hline Kassa & Ethiopia & HARC & 2.0 & 5 & 0.2 & 3 & 0.83 & 5 & 13 \\
\hline Kontu & Finland & Boreal & 2.3 & 3 & 0.3 & 7 & 1.23 & 28 & 38 \\
\hline KUSE & Ethiopia & HARC & 1.5 & 15 & 0.6 & 14 & 0.88 & 7 & 36 \\
\hline Melodie & France & INRA & 1.4 & 16 & 1.0 & 23 & 0.79 & 3 & 42 \\
\hline Messay & Ethiopia & HARC & 1.4 & 18 & 0.8 & 19 & 1.19 & 27 & 64 \\
\hline Moti & Ethiopia & HARC & 1.8 & 9 & 1.0 & 24 & 1.02 & 17 & 50 \\
\hline NC 58 & Ethiopia & HARC & 1.1 & 22 & 0.9 & 22 & 0.94 & 11 & 55 \\
\hline OBSE & Ethiopia & HARC & 2.0 & 5 & 0.6 & 15 & 0.87 & 6 & 26 \\
\hline SSNS-1 & Canada & Univ. Saskatchewan & 2.0 & 5 & 0.4 & 8 & 1.08 & 23 & 36 \\
\hline Tesfa & Ethiopia & HARC & 1.7 & 11 & 0.7 & 17 & 0.89 & 8 & 36 \\
\hline Tumsa & Ethiopia & HARC & 2.0 & 5 & 1.3 & 27 & 1.11 & 24 & 56 \\
\hline Walki & Ethiopia & HARC & 1.5 & 14 & 0.6 & 16 & 0.77 & 2 & 32 \\
\hline Wayu & Ethiopia & HARC & 1.9 & 6 & 0.5 & 12 & 0.97 & 14 & 32 \\
\hline SE & & & 0.29 & & 0.23 & & & & \\
\hline $\operatorname{LSD}(5 \%)$ & & & 0.82 & & 0.66 & & & & \\
\hline
\end{tabular}


538 Table 2. Summary of acid and aluminium responses of the 10 faba bean accessions chosen from 539 the solution culture experiment for further investigation.

\section{Aluminium response}

Tolerant Intermediate Sensitive

\begin{tabular}{|c|c|c|c|c|}
\hline \multirow{2}{*}{ Acidity } & Tolerant & NC 58, Dosha & & Kassa, GLA 1103 \\
\hline & Intermediate & Gebelcho & & \\
\hline & Sensitive & Aurora, Messay & Tesfa, EH 06006-6 & Babylon \\
\hline
\end{tabular}

540 
541 Table 3. Accessions and treatment means of leaf and nodule characters measured in either peat or 542 perlite potting media, $\mathrm{n}=4$.

\begin{tabular}{|c|c|c|c|c|c|c|}
\hline \multirow[b]{2}{*}{ Accession } & \multicolumn{4}{|c|}{ Peat experiment } & \multirow[b]{2}{*}{$\begin{array}{l}\text { Shoot } \\
\mathrm{Al} \\
(\mathrm{mg} / \mathrm{kg})\end{array}$} & \multirow{2}{*}{$\begin{array}{l}\text { Perlite experiment } \\
\text { Canopy } \\
\text { temperature }\left({ }^{\circ} \mathrm{C}\right)\end{array}$} \\
\hline & $\begin{array}{l}\text { Leaf area } \\
\left(\mathrm{cm}^{2}\right)\end{array}$ & $\begin{array}{l}\text { Photosynthesis } \\
\left(\mu \mathrm{mole} / \mathrm{m}^{2} / \mathrm{s}\right)\end{array}$ & $\begin{array}{l}\text { Nodule } \\
\text { quantity }\end{array}$ & $\begin{array}{l}\text { Nodule } \\
\text { quality }\end{array}$ & & \\
\hline Aurora & 831 & 16.4 & 2.33 & 2.50 & 43.1 & 22.5 \\
\hline Babylon & 722 & 18.6 & 1.75 & 2.42 & 44.1 & 22.8 \\
\hline Dosha & 640 & 14.8 & 1.08 & 1.58 & 45.2 & 23.2 \\
\hline ЕН 06006-6 & 551 & 15.1 & 0.83 & 1.08 & 68.6 & 23.7 \\
\hline Gebelcho & 617 & 16.9 & 0.83 & 0.92 & 42.9 & 23.0 \\
\hline GLA 1103 & 606 & 20.1 & 2.08 & 2.58 & 49.3 & 22.6 \\
\hline Kassa & 533 & 16.5 & 1.08 & 1.33 & 50.8 & 22.9 \\
\hline Messay & 547 & 17.2 & 1.67 & 2.33 & 59.5 & 22.7 \\
\hline NC 58 & 569 & 14.7 & 1.00 & 1.17 & 79.1 & 22.8 \\
\hline Tesfa & 475 & 18.3 & 0.92 & 1.33 & 72.8 & 22.2 \\
\hline $\mathrm{SE}$ & 32 & 0.72 & 0.27 & 0.32 & 8.2 & 0.24 \\
\hline LSD (5\%) & 89 & 2.02 & 0.75 & 0.90 & 23.1 & 0.66 \\
\hline \multicolumn{7}{|l|}{ Treatment } \\
\hline Neutral & 780 & 15.6 & 1.90 & 2.10 & 44.7 & 22.7 \\
\hline Acid & 491 & 16.7 & 0.98 & 1.50 & 57.4 & 22.8 \\
\hline Aluminium & 556 & 18.3 & 1.20 & 1.58 & 64.6 & 23.0 \\
\hline $\mathrm{SE}$ & 17 & 0.39 & 0.15 & 0.18 & 4.49 & 0.13 \\
\hline $\operatorname{LSD}(5 \%)$ & 49 & 1.11 & 0.41 & 0.49 & 12.7 & 0.36 \\
\hline \multicolumn{7}{|l|}{ P-value } \\
\hline Treatment & $* * *$ & ns & $*$ & $\mathrm{~ns}$ & ns & ns \\
\hline Accession & $* * *$ & $* * *$ & $* * *$ & $* * *$ & $*$ & $* *$ \\
\hline Treatment $\mathrm{x}$ Accession & ns & ns & $\mathrm{ns}$ & ns & ns & ns \\
\hline
\end{tabular}

$543 *, * *, * * * \mathrm{p}<0.05,0.01,0.001$, respectively, ns (not significant) $\mathrm{p}>0.05, \mathrm{SE}$ is standard error 
544 Table 4. Accession and treatment means of leaf, root and shoot traits measured in both peat and 545 perlite potting media, $\mathrm{n}=4$.

\begin{tabular}{|c|c|c|c|c|c|c|c|c|c|c|}
\hline \multirow[b]{2}{*}{ Accession } & \multicolumn{2}{|c|}{$\begin{array}{l}\text { Chlorophyll } \\
\text { concentration } \\
\text { (SPAD unit) }\end{array}$} & \multicolumn{2}{|c|}{$\begin{array}{c}\text { Stomatal } \\
\text { conductance } \\
(\mathrm{mol} \\
\left.\mathrm{H}_{2} \mathrm{O} / \mathrm{m}^{2} / \mathrm{s}\right)\end{array}$} & \multicolumn{2}{|c|}{$\begin{array}{c}\text { Root dry } \\
\text { weight }(\mathrm{g})\end{array}$} & \multicolumn{2}{|c|}{$\begin{array}{l}\text { Shoot dry } \\
\text { weight }(g)\end{array}$} & \multicolumn{2}{|c|}{$\begin{array}{l}\text { Root to shoot } \\
\text { dry weight } \\
\text { ratio }\end{array}$} \\
\hline & Peat & Perlite & Peat & Perlite & Peat & Perlite & Peat & Perlite & Peat & Perlite \\
\hline Aurora & 38.7 & 35.2 & 0.44 & 0.52 & 3.16 & 1.52 & 8.32 & 2.89 & 0.40 & 0.56 \\
\hline Babylon & 40.8 & 39.2 & 0.50 & 0.29 & 3.48 & 1.45 & 6.83 & 3.55 & 0.52 & 0.42 \\
\hline Dosha & 33.3 & 35.2 & 0.39 & 0.31 & 2.27 & 1.76 & 7.20 & 4.45 & 0.33 & 0.40 \\
\hline ЕH 06006-6 & 36.2 & 38.4 & 0.37 & 0.20 & 1.89 & 2.12 & 6.55 & 5.08 & 0.30 & 0.42 \\
\hline Gebelcho & 34.6 & 35.8 & 0.49 & 0.31 & 2.08 & 1.87 & 6.82 & 4.93 & 0.32 & 0.39 \\
\hline GLA 1103 & 39.7 & 40.2 & 0.62 & 0.47 & 2.40 & 1.44 & 6.11 & 2.89 & 0.43 & 0.53 \\
\hline Kassa & 34.8 & 34.2 & 0.50 & 0.37 & 1.75 & 1.57 & 6.31 & 3.85 & 0.28 & 0.41 \\
\hline Messay & 34.3 & 36.1 & 0.47 & 0.29 & 1.88 & 1.52 & 6.40 & 4.42 & 0.30 & 0.34 \\
\hline NC 58 & 34.7 & 36.1 & 0.41 & 0.28 & 2.03 & 1.52 & 7.08 & 4.40 & 0.30 & 0.35 \\
\hline Tesfa & 35.4 & 34.8 & 0.58 & 0.36 & 1.61 & 1.66 & 5.11 & 4.82 & 0.34 & 0.35 \\
\hline SE & 0.61 & 0.79 & 0.04 & 0.03 & 0.13 & 0.11 & 0.32 & 0.25 & 0.02 & 0.03 \\
\hline $\operatorname{LSD}(5 \%)$ & 1.72 & 2.21 & 0.10 & 0.08 & 0.37 & 0.30 & 0.89 & 0.70 & 0.06 & 0.07 \\
\hline \multicolumn{11}{|l|}{ Treatment } \\
\hline Neutral & 34.5 & 35.1 & 0.35 & 0.37 & 2.43 & 1.77 & 5.38 & 4.34 & 0.28 & 0.42 \\
\hline Acid & 37.4 & 36.7 & 0.51 & 0.33 & 2.05 & 1.59 & 6.10 & 3.94 & 0.39 & 0.42 \\
\hline Aluminium & 36.8 & 37.7 & 0.56 & 0.32 & 2.28 & 1.57 & 8.54 & 4.10 & 0.39 & 0.41 \\
\hline SE & 0.33 & 0.43 & 0.02 & 0.02 & 0.07 & 0.06 & 0.17 & 0.14 & 0.01 & 0.014 \\
\hline $\operatorname{LSD}(5 \%)$ & 0.94 & 1.21 & 0.06 & 0.05 & 0.20 & 0.16 & 0.49 & 0.39 & 0.03 & 0.04 \\
\hline \multicolumn{11}{|l|}{ P-value } \\
\hline Treatment & $* *$ & $* *$ & $*$ & ns & ns & ns & $* * *$ & ns & $*$ & ns \\
\hline $\begin{array}{l}\text { Accession } \\
\text { Treatment } \mathrm{x}\end{array}$ & $* *$ & $* * *$ & $* * *$ & $* * *$ & $* * *$ & $* * *$ & $* * *$ & $* * *$ & $* * *$ & $* * *$ \\
\hline Accession & ns & $* *$ & ns & $\mathrm{ns}$ & ns & ns & $\mathrm{ns}$ & ns & ns & ns \\
\hline
\end{tabular}

$*, * *, * * * \mathrm{p}<0.05,0.01,0.001$, respectively, ns (not significant) $\mathrm{p}>0.05, \mathrm{SE}$ is standard error 


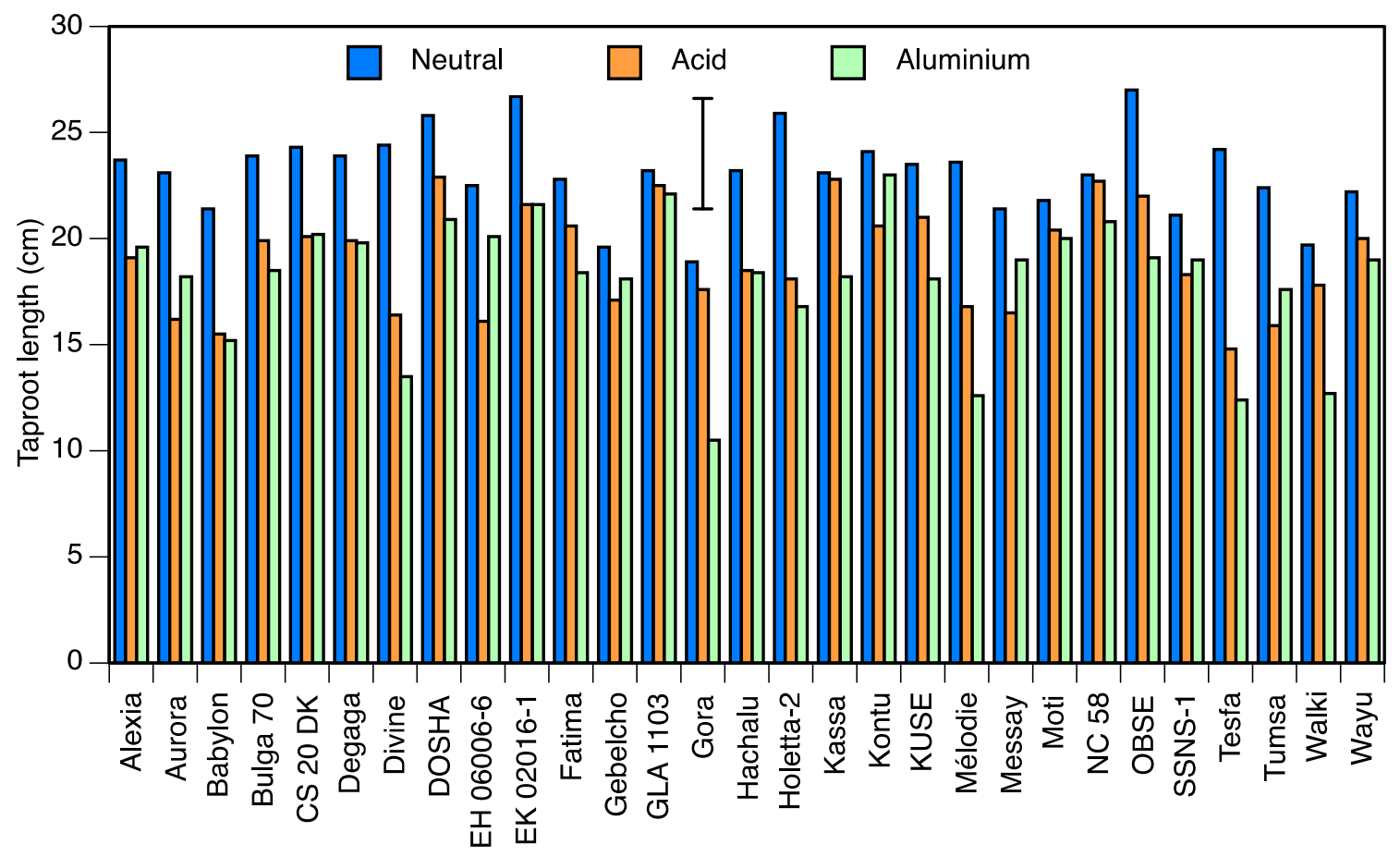

548 Figure 1. Taproot lengths in solution culture.

549 Taproot length of seedlings of 29 accessions of faba bean grown in solution culture for 10 days 550 in neutral ( $\mathrm{pH} 7.0)$ or acid ( $\mathrm{pH} 4.5)$ nutrient solution, or 8 days in the acid solution followed by 2 551 days in aluminium-containing acid $\left(\mathrm{pH} 4.5,82 \mu \mathrm{mol} / 1 \mathrm{Al}^{3+}\right)$ solutions. Error bar shows LSD (5\%).
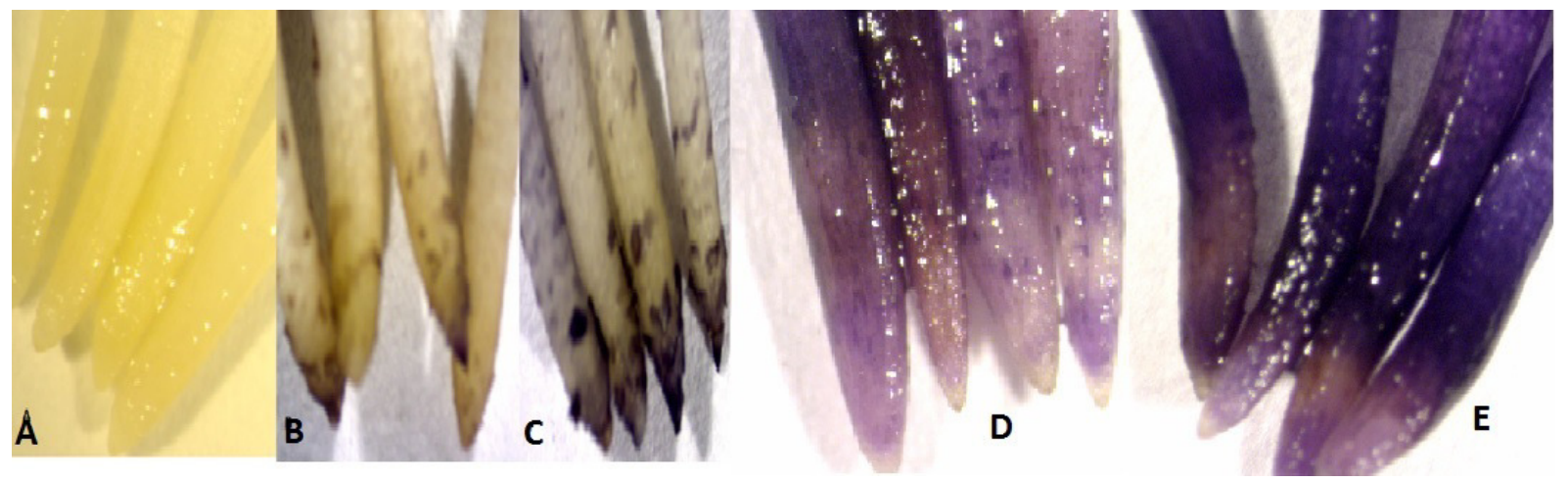

Figure 2. Haematoxylin staining of root tips of faba bean.

$556 \mathbf{A}$, acid treatment without aluminium; B-E, after $82 \mu \mathrm{mol} / 1 \mathrm{Al}^{3+}$ treatment; B, accession Dosha, 557 score $0, \leqslant 25 \%$ stain; $\mathbf{C}$, accession Aurora, score $1,25 \%<x \leqslant 50 \%$ stain; $\mathbf{D}$, accession Wayu, 558 score 2, $50 \%<x \leqslant 75 \%$ stain; $\mathbf{E}$, accession Babylon, score 3, $>75 \%$ stain. 


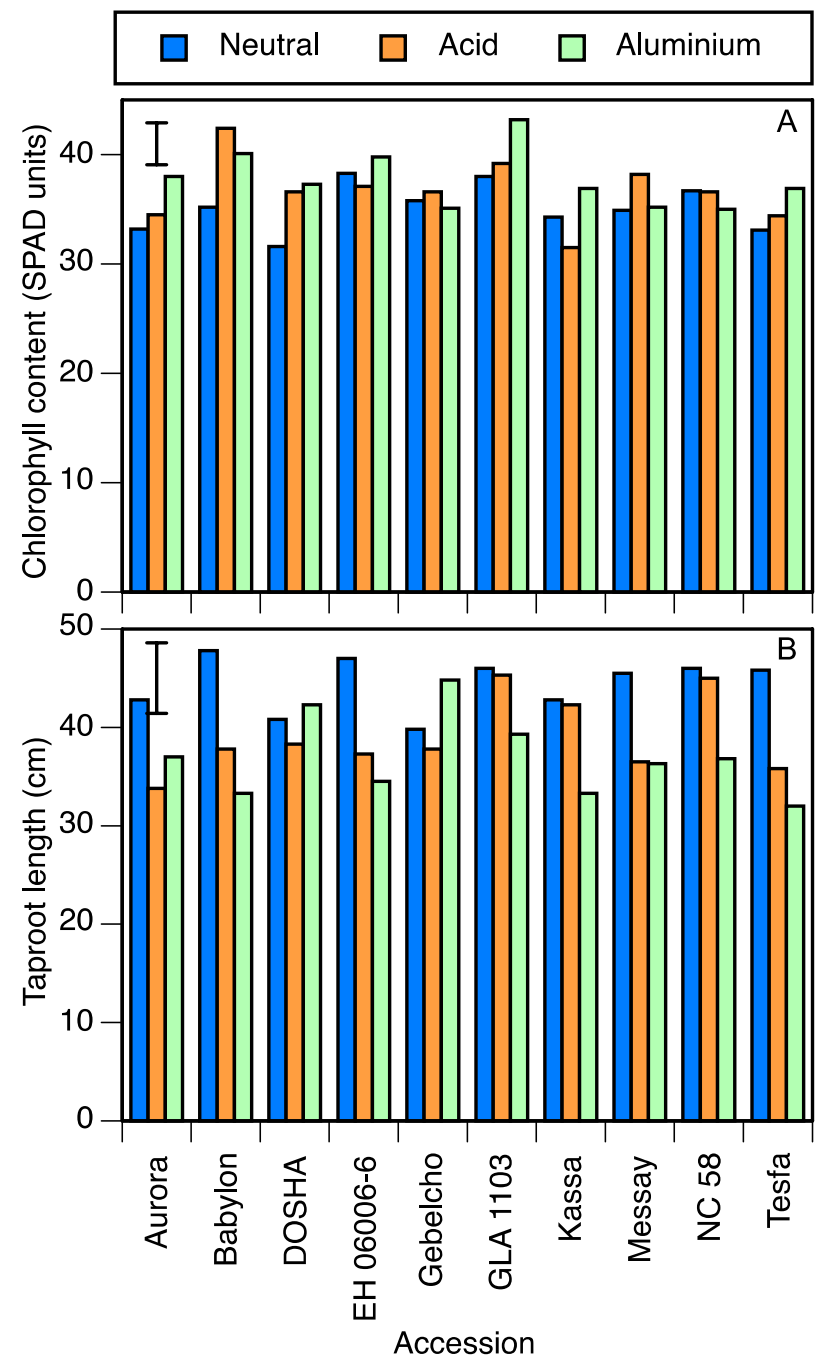

562 Figure 3. Chlorophyll concentration and taproot length.

563 A, Chlorophyll concentration (SPAD units) and B, taproot length ( $\mathrm{cm}$ ) in 10 accessions of faba 564 bean grown in perlite and fertigated with neutral $(\mathrm{pH} 7)$, acid $(\mathrm{pH} \mathrm{4.5)}$ or aluminium containing

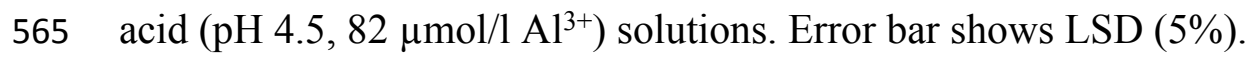

